\title{
Wywiady z uczestnikami hungarologicznej konferencji w Poznaniu
}

Rita Hegedús (Uniwersytet Humboldtów, Berlin)

1. Jaka rolę może petnić język węgierski na świecie?

$\mathrm{Z}$ uwagi na swoją wyjątkową budowę - w czym różni się od języków indoeuropejskich - język węgierski może służyć innym językom jako typologiczne tertium comparationis. Poza tym jest „nieeuropejskim” nośnikiem europejskiej kultury.

2. Na czym polega uczenie hgungarologii za granica?

Ta dziedzina ma szeroki zakres: wykłada się podstawy historii kultury, dziejów, literatury i językoznawstwa. Nauka w tej dziedzinie nie ma końca.

3. Na czym mogłaby polegać wspótpraca filologii węgierskich za granica?

Poza współpracą zawodową - opracowywaniem materiałów dydaktycznych, projektami badawczymi - najważniejsze zadanie polega, jak sądzę, na rozpowszechnianiu wiedzy o węgierskiej kulturze bez wikłania się w politykę. Poznawanie dokonań konkretnego świata musi odbywać się w obcym języku. Tylko ci nauczą się języka, w których zdołaliśmy wzbudzić zainteresowanie tematem. Według mnie szczególnie ważne jest też rozwijanie i budowanie więzi pomiędzy studentami hungarystyk w poszczególnych krajach. To oni trzymają przed nami lustro, żebyśmy byli otwarci na świat i dotrzymywali kroku oczekiwaniom, jakie świat stawia przed hungarologią.

4. W jakim zakresie poznańska konferencja hungarologiczna okazała się przydatna?

W części poświęconej językoznawstwu wyraziście naszkicowano badawcze punkty widzenia. Ujawniły się bliższe związki pomiędzy pojedynczymi polami badawczymi, wykazano obiecujące możliwości współpracy nad ich badaniem. W ciekawy, ale także zaskakujący sposób ujawniła się różnica między perspektywą formalną a funkcjonalno-kognitywną. Konferencja jednoznacznie uzmysłowiła nam, że nauczanie MID/ hungarologii domaga się postrzegania jej jako osobnej dziedziny i wymaga specjalistycznego przygotowania. W przypadku młodych fachowców powinno ono polegać na harmonijnym połączeniu teorii i praktyki. Konferencja była bardzo pożyteczna, przeważały kompetentne referaty. Dobra atmosfera, dobra organizacja, dziękujemy organizatorom.

Sára Magyari (Uniwersytet Katolicki Partium, Kluż-Napoka)

1. Jaka jest sytuacja języka węgierskiego (języka węgierskiego jako ojczystego i języka węierskiego jako obcego) w Rumunii?

Sytuacja języka węgierskiego jako ojczystego zależy od poszczególnych regionów i grup. Nie bez znaczenia pozostaje fakt, czy mówimy o bardzo licznej grupie węgierskojęzycznej (ponad $50 \%$ ), o Węgrach przebywających w kraju tymczasowo (około $20 \%$ ), czy o węgierskiej diasporze (mniej niż 20\%). De iure sytuacja nie jest 
beznadziejna, ale opracowywane wyniki badań pokazują tylko część prawdy. Często zależy to od siły regionalnej wspólnoty, od strategii zasiedlania konkretnego terenu, ale także od skuteczności pojedynczych osób. Jeśli mówimy o sytuacji MID, języka węgierskiego jako obcego języka, obraz jest jeszcze bardziej zróżnicowany. Urzędowo nie istnieje coś takiego, jak język węgierski jako język obcy. Mówi się raczej o węgierskim jako języku ojczystym mniejszości, ale rzeczywistość znowu to weryfikuje. Do szkół prowadzonych po węgiersku chodzi coraz więcej uczniów, dla których językiem ojczystym nie jest węgierski. W takich sytuacjach trzeba (na nowo) uczyć języka. Posługuję się skrótem MID jako pojęciem czysto pedagogicznym, skłaniam się raczej ku pojęciu język węgierski jako język środowiskowy lub węgierski jako język pochodzenia. W Rumunii ministerstwo opracowuje teraz programy nauczania, które przydałyby się we wspomnianych sytuacjach.

2. Jak mogłaby wyglądać wspótpraca filologii węgierskich za granica kraju?

Podkreśliłabym znaczenie ciągłej wymiany doświadczeń, nie musiałyby to być wyłącznie konferencje, ale rozmowy warsztatowe, wspólne badania. Należałoby uczynić bardziej płynnymi granice, bo choć wiele się o tym mówi, w praktyce filologów węgierskich dzieli się na tych, którzy pracują na Węgrzech i resztę. Ważne byłoby włączenie dziedzin istotnych w kształceniu poza granicami kraju, czy to literatury, czy językoznawstwa, czy folkloru. Kluczowe byłoby odejście od romantycznego obrazu krajan żyjących poza ojczyzną. W nauczaniu MID należałoby zaś podążyć w innym kierunku: wypracować wspólny trzon (dobrze pokrywa się on z KER), ale porzucić próby sprostania lokalnym wymaganiom. Sądzę, że staje się to rzeczywistością. Za ważne uznałabym także koordynację instytucji węgierskich (mamy na to dobre przykłady) i korzystanie z ich pomocy. Na przykład mogłyby pomóc w lokalnych formach kształcenia, w opracowywaniu materiałów pomocniczych, ale nie wymuszałyby stosowania krajowych podręczników, które w nauczaniu poza granicami kraju nie wszędzie są przydatne.

\section{Dorota Dziewońska-Kiss (ELTE, Lengyel tanszék)}

1. Na ile intensywne sa relacje węgiersko-polskie, $w$ czym się przejawiają?

Między uniwersytetami kontakty stopniowo umacniają się. Coraz częściej miejsce mają: wymiana wykładowców, wzajemne zaproszenia na konferencje oraz wyjazdy studentów. Wykładowcy obu uczelni są ze sobą w stałym kontakcie, szczególnie w sprawach dotyczących nauczania, publikacji, organizacji konferencji oraz udziału we wspólnych projektach i konkursach.

2. W jakim stopniu węgierski językowy obraz świata podobny jest do polskiego językowego obrazu świata, a w jakim stopniu różni się od niego?

Temat językowego obrazu świata coraz częściej staje się przedmiotem badań naukowych oraz tematem konferencji. W obu językach zauważalne jest wiele podobieństw (np. sposób wartościowania nazw zwierząt, roślin, części ciała itp.) oraz różnic. Znajomość sposobu konceptualizacji i kategoryzacji rzeczywistości obiektywnej jest 
nieunikniona jeśli chcemy zapobiec popełnianiu błędów podczas tłumaczenia tekstów czy konwersacji.

3. W jaki sposób węgierska i polska filologia mogtyby wspótpracować?

Większą uwagę należałoby zwrócić na wymianę między studentami, gdyż ogromne znaczenie w rozwijaniu kompetencji językowych ma czas spędzony w danym środowisku językowym. Ważne byłoby również wspieranie możliwości publikacji w obu krajach, organizacji konferencji, warsztatów językowych i literaturoznawczych, spotkań wykładowców.

4. Na ile byla pożyteczna poznańska konferencja?

Podczas poznańskiej konferencji zapoznaliśmy się z wieloma nowymi tematami badań naukowych. Wzmocniły się relacje między poszczególnymi przedstawicielami placówek naukowych, omówione zostały problemy dotyczące wzajemnej współpracy, nawiązano nowe kontakty.

Konferencja była na bardzo wysokim poziomie naukowym. Bardzo dobrze, sprawnie zorganizowana. Obrady przebiegały w miłej, przyjaznej atmosferze. Owocne były zarówno obrady jak i spotkania poza nimi. 